Uludag Univ. J. Fac. Vet. Med.

34 (2015), 1,2: 85-88

\title{
Bir Köpekte Primer İntranazal Transmissible Venereal Tümör (TVT)
}

\author{
Hilal ÇEŞME $^{1} \quad$ Volkan IPPEK $^{2} \quad$ Ahmet AKKOÇ$^{2} \quad$ Hakan SALCI $^{1}$
}

Geliş Tarihi: 06-08-2015

Kabul Tarihi: 18-11-2015

\begin{abstract}
Özet: Coli melezi, erkek, 2,5 yaşlı köpek burun ve göz akıntısı, gözün altında farklı kanlı bir akıntı görünümü, burun ve damak şişkinliği şikayetleriyle getirildi. Klinik olarak sağ gözün medial açısının altında fistül deliği, maksilla ve nazal kemik ve palatum molle de şişkinlik saptandı. Radyolojik olarak burun boşluğu içerisinde muhtemel yumuşak doku opasitesi artışı görüldü. Akıntılardan swapla ve damaktaki şişkinlikten ince iğne aspirasyonuyla alınan numunelerde sitolojik olarak çok sayıda yangı hücresi ve geniş sitoplazmalı, yoğun kromatin yapısına sahip yuvarlak çekirdekli tümör hücreleri belirlendi. Primer TVT tanısı konulan köpek dört haftalık vinkristin sülfat kürü ile tedavi edildi. Yakın dönemde nüks gözlenmedi. Sunulan bu olgu ile primer intranazal TVT’nin rapor edilmesi ve tedavi sonucunun veteriner hekimlerle paylaşılması amaçlanmıştır.
\end{abstract}

Anahtar Kelimeler: Köpek, nazal boşluk, transmissible venereal tümör.

\section{Primary Intranasal Transmissible Venereal Tumor (TVT) in a Dog}

\begin{abstract}
Coli croos breed, male, 2.5 year-old dog was presented with the complaint of nasal and eye discharge, a different bloody fluid view under the eye, swelling of the nose and palate. Clinically, a fistula under the medial angle, swelling on the maxillary and nasal bones and palatum molle were determined. Radiologically, possible increased soft tissue opacity was observed in the nasal cavity. A plenty of inflammation cells and tumor cells, which had dense chromatin form and round nucleus, were detected in samples taken by swap from fluids and by fine needle aspiration from swelling on palate. For four weeks, the dog diagnosed primary TVT was treated with vincristine sulphate cure. No recurrence was observed in early stage. With this case, it was aimed to report primary intranasal TVT and share the treatment results with the veterinarians.
\end{abstract}

Key Words: Dog, nasal cavity, transmissible venereal tumor.

\section{Giriş}

Köpeklerde transmissible venereal tümör (TVT), sticker sarkom, histiyositoma, veneral granuloma, transmissible lenfosarkom ve kontagiöz venereal tümör adlarıyla da bilinen bir tümördür ${ }^{4,5}$. Özellikle seksüel aktif olan genç yaştaki ve serbest dolaşan köpeklerde görülür ${ }^{1,4}$. Hastalığı taşıyan köpekler sağlıklılara hücre nakli (çiftleşme) yoluyla tümörü aktarmaktadır ${ }^{5}$.

TVT, genellikle penis ve vagina mukozasin1 etkilemektedir ${ }^{4}$. Küçük yaşta, vücut direnci zayıf ve immunsupresif köpeklerde daha agresif ve metastazik olmaktadır. TVT, genital yerleşiminin yanı sıra ekstragenital organlarda da $\% 5$ oranında görülmektedir ${ }^{1,2}$. Bu yerleşim ya genital form ile birlikte ya da sadece ekstragenital olmaktadır. Ekstragenital lokalizasyonlar koklama, yalama veya isırma esnasinda direkt temasla oluşur ${ }^{1}$. Ancak oral ve nasal boşlukta daha nadir rastlanmaktadır ${ }^{2}$. Sunulan bu olgu ile bir köpekte nasal boşlukta karşılaştığımız primer TVT'nin rapor edilmesi ve tedavi sonucunun meslektaşlarımızla paylaşılması amaçlanmiştır.

1 Uludağ Üniversitesi Veteriner Fakültesi, Cerrahi Anabilim Dalı, Bursa. hsalci@uludag.edu.tr

2 Uludağ Üniversitesi Veteriner Fakültesi, Patoloji Anabilim Dalı, Bursa. 


\section{Olgunun Tanımı}

Yaklaşık 2,5 yaşl1, Coli melezi, erkek bir köpek kanlı burun ve göz akıntısı, gözün altından farklı bir irinli ve kanlı akıntı gelmesi, burun ve damakta şişkinlik şekillenmesi şikayetleriyle Uludağ Üniversitesi Veteriner Fakültesi Cerrahi Anabilim Dalı Klinikleri'ne getirildi.

Klinik muayenede genel durumu normal olan köpeğin her iki gözde irinli akıntı, burun deliklerinden de kanlı akıntı geldiği belirlendi. Ayrıca maksillar ve nazal kemiği içeren diffüz bir şişkinlik de saptandı. Sağ gözün medial açısinın hemen önünde nazal kavite ile bağlantılı bir fistül deliği görüldü (Şekil 1). Oral muayenede, palatum molle' de oral yöne doğru genişleyen $5 \times 5 \mathrm{~cm}$ çapında neoplastik bir şişkinlik gözlendi. Vücudun diğer organ ve organellerinde (ürogenital ve diğer sistemlere ait) herhangi bir tümöral klinik görünüm de belirlenmedi.

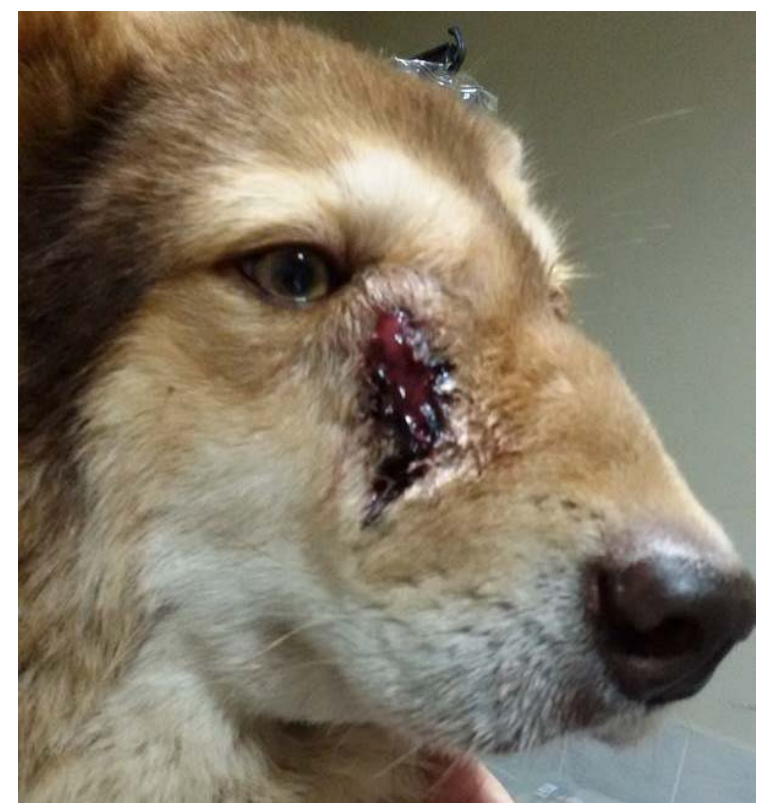

Şekil 1. Olgunun ilk sunulan, tedavi öncesi görünümü.

Figure 1. Initial presented, pre-treatment view of the case.

Alınan cranium ve os nasalenin radyografilerinde burun boşluğu içerisinde yumuşak doku görünümlü opasite artışı dikkati çekti (Şekil 2). Toraks grafisinde herhangi bir anormal radyolojik görünüm belirlenmedi.

Burun ve gözyaş1 akıntılarından swapla, palatum molledeki şişkinlikten ise ince iğne aspirasyonuyla sitolojik inceleme için numuneler alındı. Numuneler lama yayıldı ve hazırlanan preparatlar Hemacolor ${ }^{\circledR}$ (Merck, İstanbul) ile boyanarak ış1k mikroskopta değerlendirildi.

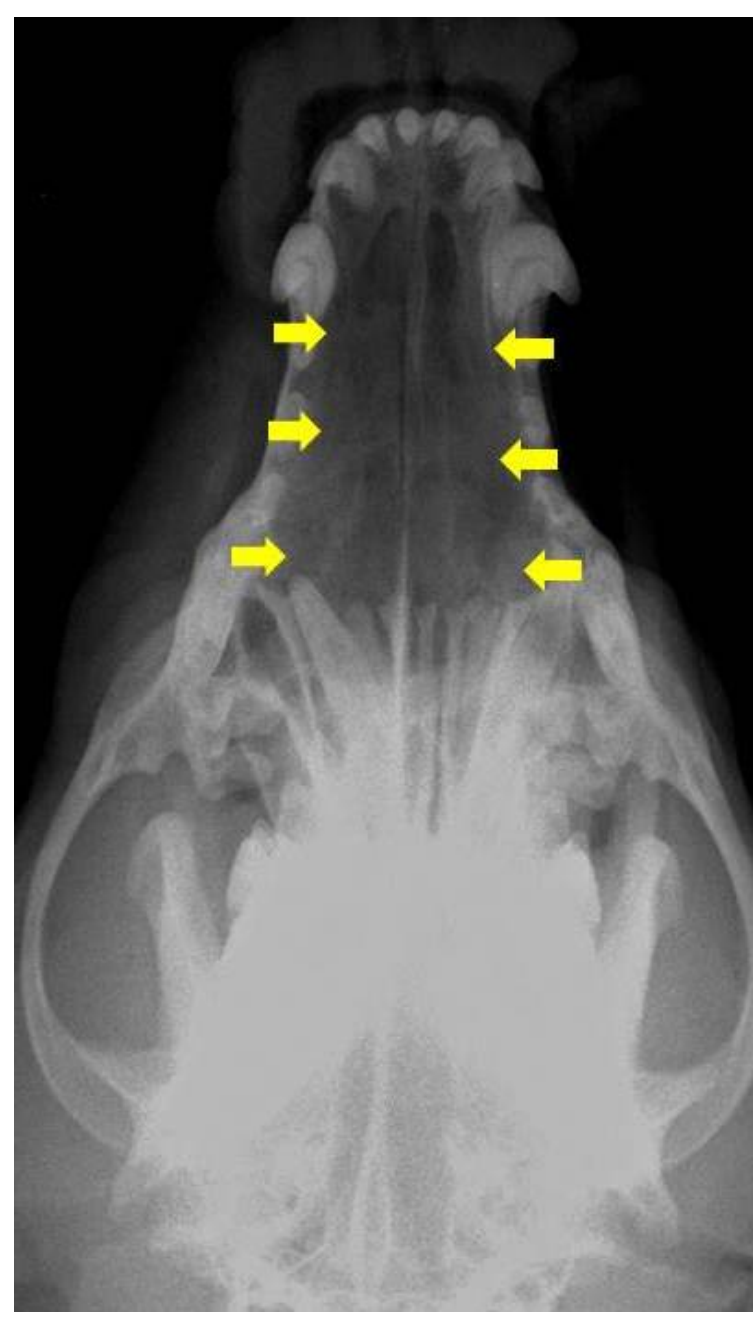

Şekil 2. Craniumun ventrodorsal ă̆ız-açık radyografide görülen nazal boşluk içerisinde artmış muhtemel yumuşak doku opasitesi (oklar).

Figure 2. Increased possible soft tissue opacity in the nasal cavity observing in the ventrodorsal open-month radiograph of the cranium (arrows).

Preparatlarda çok sayıda nötrofil lökosit ile birlikte az sayıda lenfosit, plazma hücresi ve makrofajlar görüldü. Yangı hücreleri ile birlikte hafif bazofilik boyanma özelliği gösteren geniş sitoplazmalı ve yoğun kromatin yapısına sahip yuvarlak çekirdekli tümör hücreleri de saptandi. $\mathrm{Bu}$ hücre çekirdeklerinin genellikle merkezi ve yer yer periferik yerleşimli olduğu, hemen tümünde tek bir belirgin çekirdekçiğin bulunduğu tespit edildi. Bu hücrelerin birçoğu sitoplazmik vakuoller içermekteydi. Hücreler arasında orta derecede anizositozis-anizokaryozis bulunmaktayd. Sitopatolojik veriler 1şığında ekstragenital intranasal primer TVT tanısı konuldu (Şekil 3). 


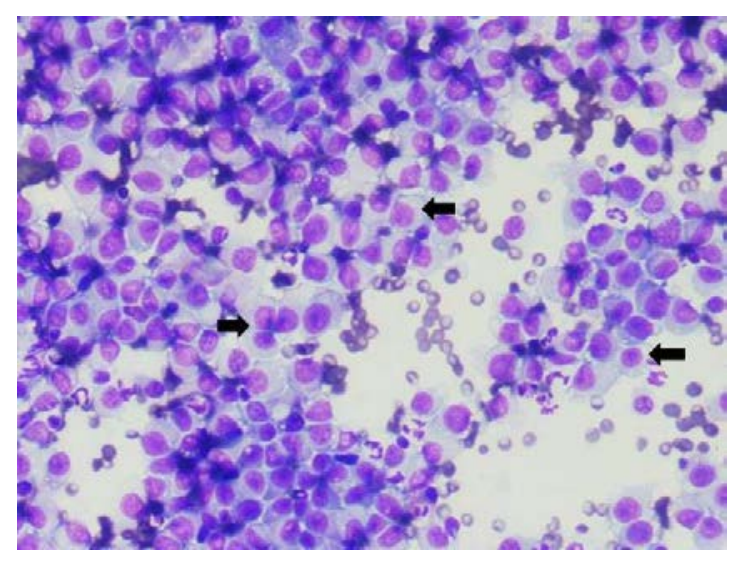

Şekil 3. Geniş ve vakuoler sitoplazmal, yuvarlak çekirdekli ve belirgin çekirdekçiğe sahip TVT hücrelerinin (oklar) sitolojik görünümü, Hemacolor, 200x.

Figure 3. Cytologic appearance of TVT cells (arrows) with wide and vacuolar cytoplasm, round nuclei and distinct nucleoli, Hemacolor, x200.

Tedavide 4 hafta süreyle haftada bir kez olmak üzere $0,025 \mathrm{mg} / \mathrm{kg}$ dozunda intravenöz yolla vinkristin sülfat (Vincristine, DBL $\AA$, Mayne Pharma Pty Ltd, Melbourne, Avustralya) $500 \mathrm{ml} \% 0.09$ 'luk izotonik $\mathrm{NaCl}$ içerisinde infüze edildi. Üçüncü haftanın sonunda kanlı burun akıntısının kesildiği, şişkinliğin gerilediği görüldü. Dördüncü haftanın sonunda ise lezyonların tamamen kaybolduğu ve köpeğin sağlığına kavuştuğu belirlendi (Şekil 4). Herhangi bir yakın dönem nüksü ile karşılaşılmadı.

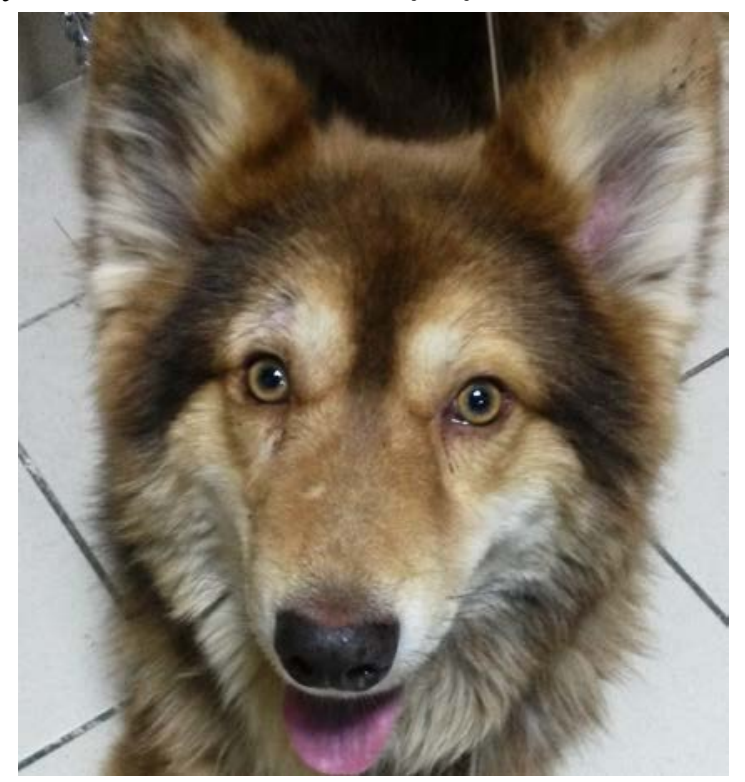

Şekil 4. Vinkristin sülfat uygulama sonrasında olgunun klinik görünümü.

Figure 4. Clinical view of the case after vincristine sulphate administration.

\section{Tartışma}

TVT, tropikal ve subtropikal bölgelerde yaşayan sokak köpeklerinde yaygın olarak gözlenen bulaşıcı bir neoplastik hastalıktır' ${ }^{2}$. Genellikle seksüel aktivite ile bulaşmaktadır ancak mukoz membranların direkt teması ile de hastalık taşınabilmektedir ${ }^{1}$. Seksüel olarak aktif, 2-5 yaşlı her irk ve cinsiyet köpeklerde hastalık görülebilmektedir ${ }^{3-6}$. Sunulan olgu 2,5 yaşl1, Coli melezi bir köpektir ve yapılan sitolojik inceleme sonucu ekstragenital bölgede primer intranasal TVT tanısı konulmuştur.

Ekstragenital TVT olgularına ait rapor bulunmaması ve primer TVT gözlenen köpeklerin tümüne de nekropsi yapılamaması nedeniyle, ülkemizdeki ekstragenital yerleşimli TVT olgularının insidensi hakkında yorum yapılamadığ bildirilmiştir ${ }^{1}$. Ayrıca ekstragenital yerleşimli TVT'nin biyolojik davranış1 ve patogenezisi tam olarak hala açıklanamamıştır ${ }^{3}$. Erkek köpeklerde tümörün dış genital organlarda, daha çok penisin kaudalinde şekillendiği, buna rağmen krura penisten, bulbus glandise ve glans penise kadar yayılabileceği ve daha az olarak prepusyum altında oluşabileceği bildirilmiştir ${ }^{1}$. Ekstragenital yerleşim yeri olarak deri, subkutan dokular, lenf dügümleri, kemikler, dalak, karaciğer, böbrek, beyin, hipofiz, göz ve oral mukoza tanımlanmıştır ${ }^{1,5}$. Bu olguda genital organlarda tümöral kitlelere rastlanmadı. Ayrıca da klinik muayenede diğer organ ve organellere ilişkin de bulgular klinik ve radyolojik (toraks) olarak gözlenmedi.

TVT hücrelerinin orijin aldığı doku bilinmemektedir. Tümörün genital organ yerleşimi olmaksızın, ekstragenital olarak da görülebilmesi nedeniyle morfolojik olarak bazı yumuşak doku ve kemik doku tümörleriyle ayırt edilmesi gerekir ${ }^{1}$. Kemoterapi oldukça efektif bir sağaltım şeçeneğidir ve klinik olaraktan da pratik bir uygulamadır. Kematerapödik ajan olarak kullanılan vinkristin sülfat'1n 2-8 injeksiyonu ile tam bir iyileşme sağlanmaktadır ve en sık kullanılan ilaç olarak belirtilmektedir ${ }^{5}$. Tanımlanan olguda tümörün mikroskobik bulgular1 incelendiğinde ekstra genital primer TVT tanısı konulmuş olup 4 haftalık periyodik vinkristin sülfat kematerapödik ajan uygulaması ile erken dönem rekurrens olmaksızın etkili bir tedavi prosedürü ile bu olguda başarı sağlanmıştır. 


\section{Kaynaklar}

1. Gülbahar, M.Y., Hazıroğlu, R. 1995. Bir köpekte ekstragenital metastazlı transmissible venereal tümör olgusu. Ankara Üniv Vet Fak Derg, 42, 441-444.

2. Pachaly, J.R., Werner, P.R., Ciffoni, E.M.G., Dantas, J.C., Tanaka, N.M. 1999. Invasive and destructive transmissible venereal tumor in the nasal cavity of a dog. Arq Ciên Vet Zool Unipar, 2(1), 77-80.

3. Papazoglu, L.G., Koutınas, A.G., Plevrakı, A.G., Tont1s, D. 2001. Primary intranasal transmissible venereal tumor in the dog: a retrospective study of six spontaneous cases. $J$ Vet Med A, 48, 391400.

4. Pigatto, J.A.T., Hünning, P.S., Bercht, B.S., Albuquerque, L. 2011. Transmissible venereal tumor in the palpebral conjuctiva of a dog. Ciênc Agrár Londrina, 32(3), 1139-1144.

5. Shiju Simon, M., Vairamuthu, S., Justin William, B., Kannan, T.A. 2011. Transmissible Venereal Tumor in the Nasal Cavity of a Dog. Tamil Nadu $J$ Vet Anim Sci, 7(6), 307-308.

6. Varela, Y.D.M., Queiroz, G.F., Filgueira, K.D., Reis, P.F.C.C., Lima, R.K.R. 2013. Transmissible venereal tumor in impuberal canine. Braz J Vet Pathol, 6(3), 123-127. 